REPORTS OF MORPHOLOGY
$\begin{gathered}\text { Official Journal of the Scientific Society of Anatomists, } \\ \text { Histologists, Embryologists and Topographic Anatomists } \\ \text { of Ukraine } \\ \text { journal homepage: https://morphology-journal.com }\end{gathered}$

\title{
Structural and functional state of the liver in patients with extrahepatic cholestasis of non-tumor genesis
}

Shevchenko B.F., Zeleniuk O.V., Klenina I.A., Babii O.M.

SI "Institute of Gastroenterology of the National Academy of Medical Sciences of Ukraine", Dnipro, Ukraine

\section{ARTICLE INFO}

Received: 10 September, 2019

Accepted: 23 October, 2019

UDC: $616.36 / .367-06-071-089.81$

\section{CORRESPONDING AUTHOR}

e-mail: zeleniuk.a.v@gmail.com

Zeleniuk O.V.

\begin{abstract}
To date, the diagnosis and treatment of extrahepatic cholestasis (EHC) at various stages of development remains one of the most pressing problems of modern biliary surgery. The purpose of the study is to determine the structural changes of the liver in patients with EHC of non-tumoral genesis according to shear wave elastometry and ultrasound in comparison with biochemical indicators of endotoxemia, inflammation and markers of fibrosis. Preoperatively, 121 patients with EHC of non-tumoral genesis were examined: standard general clinical studies, ultrasound examination of the liver and its shear wave elastometry were performed. Depending on the presence of jaundice and symptoms of hepatocyte damage, all the patients were divided into 4 groups. Serum content of medium molecular weight peptides, free hydroxyproline and glycosaminoglycans was determined. Statistical processing of the obtained data was performed using SPSS 16.0. In patients with EHC of non-tumoral genesis according to shear wave elastography, the stiffness of the liver varied depending on the increase in the intensity of jaundice. It was found that the serum bilirubin level in such patients was significantly different depending on the available jaundice and symptoms of hepatocyte damage both in comparison with the control group and between the study groups. In EHCs, structural changes in the liver depend on abnormalities in the biochemical composition of serum, which are significantly altered by prolonged extrahepatic cholestasis and manifested by severe liver failure. Thus, an increase in endotoxemia $(p<0.001)$ was found in patients with $E H C$ of non-tumoral genesis without jaundice and evidence of cholestasis development; indicators of liver stiffness depend on the level of bilirubinemia $(r=0.84)$, and in patients with hepatocyte damage also on the duration of cholestasis $(r=0.68)$. Bilirubin levels cannot be an indicator of long-term EHC.

Keywords: extrahepatic cholestasis of non-tumor genesis, elastometry, markers of endogenous intoxication, damage to hepatocytes.
\end{abstract}

\section{Introduction}

The term "cholestasis" of Greek origin literally means

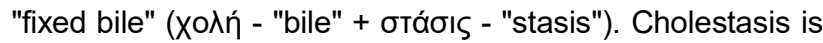
one of the main processes that occur in the liver in the development of diseases of different etiology. Cholestasis syndrome is a clinical-laboratory syndrome characterized by an increase in bilirubin and bile excreted substances in the blood as a result of impaired synthesis or outflow. Actually, the term "cholestasis" in its modern sense was introduced by Popper and Schaffer only in 1970 to designate not only the mechanical causes of impaired bile flow, but also in connection with impaired secretion of its individual components, primarily impaired hepatocyte function (intrahepatic cholestasis) [1]. From the point of view of the development of the disease in accordance with the structure and structure of the bile ducts, depending on the level of the block, hepatocellular, tubular and duct cholestasis are distinguished. When viewed in a larger format, isolated hepatic and extrahepatic cholestasis $(\mathrm{EHC})$ are classified. EHC have been known since ancient times, whereas intrahepatic cholestasis has caught the attention of physicians only in the mid-twentieth century. Until the 1960s, bile passages at all levels were associated solely with mechanical obstruction of the duct system, which arose as a complication of gallstone disease.

In the next 15 years, an increase in the worldwide incidence of pathology of the biliary system is projected (by $30-50 \%$ ), which is caused by hereditary factors, changes in the nature of nutrition and a sedentary lifestyle. It should be 
noted that over the past 10 years, there has been a steady trend of increasing incidence of cholelithiasis, which is accompanied by the development of extrahepatic cholestasis $[2,3,4,5,10]$.

Functional EHC is most often caused by Oddi sphincter dysfunction. Obstructive EHC, or mechanical jaundice, is a persistent violation of the excretion of bile from the bile ducts and gallbladder into the lumen of the duodenum, which can be caused by obstruction of the bile ducts by gallstones, helminths or mechanical compression of the bile ducts from the outside by tumor (pancreatic head, large duodenal papilla, common bile duct, enlarged gallbladder), inflammatory swelling of the mucous membrane of the biliary passages (non-purulent, sclerosing or purulent cholangitis), bile duct stricture and other factors. Violation of the outflow of bile leads to its stagnation, increasing the pressure in the bile capillaries, their overstretching, increasing the permeability of the walls and their rupture, which promotes the flow of bile directly into the blood. The appearance of bile in the blood leads to the development of cholemic syndrome, and with complete obstruction of the bile ducts and the cessation of bile flow to the intestine (clinically, this is manifested in the acholic stool).

At detection of a syndrome of a cholestasis at the patient, for doctor it is necessary to make qualitative differential diagnostics with precise determination of degree and place of formation of the block and it is unacceptable to establish the diagnosis without excluding the possible causes of cholestasis. Diagnostic errors that occur in $12-38 \%$ of cases of cholestasis [3] lead to loss of precious time, occurrence of liver failure or other serious complications (gastrointestinal bleeding, purulent cholangitis, liver abscesses, sepsis) that in $14-27 \%$ of observations lead to death $[1,3,8,9,10]$.

To date, prevention and treatment of $\mathrm{EHC}$ at various stages of development remains one of the most pressing problems of biliary surgery. There is evidence [11, 12, 13] that EHC affect the elasticity of the liver, but to date, the possibilities of using elastography to assess the functional and morphological status of the liver in EHC of nontumorigenesis have not been sufficiently studied. Recently, several ultrasound and radiological methods have been developed to quantify liver elasticity. One of the most accurate and common among them is the method of shear wave elastography (SWE).

The basis of the method of shear wave elastography is the property of the ultrasonic beam to generate transverse mechanical shear waves in the direction of its propagation. The speed of their passage through the fabric depends on its stiffness or visco-elastic properties. The digital expression of liver stiffness is determined in kilopascals $(\mathrm{kPa})$ from a specific control volume of the liver parenchyma [11-13]. However, the effect of EHC on liver elasticity in comparison with non-invasive serum markers of endotoxemia, inflammation, and fibrosis has not been studied.

Purpose of the study: to determine structural changes of the liver according to shear wave elastometry and ultrasound in comparison with biochemical indicators of endotoxemia, inflammation, markers of fibrosis in patients with non-hepatic cholestasis of non-tumoral genesis.

\section{Materials and methods}

The data of the examination of 121 patients with EHC of non-tumoral genesis who were undergoing treatment at the department of digestive surgery of the State Institution "Institute of Gastroenterology of the National Academy of Medical Sciences of Ukraine" for the period from 2013 to 2019 were analyzed.

Extrahepatic cholestasis in 22 patients (18.18\%) patients was caused by chronic calculous cholecystitis with the phenomena of Oddi sphincter, in 28 patients (23.14\%) choledocholithiasis after cholecystectomy, in 18 patients $(14.87 \%)$ - stenotic papillitis after cholecystectomy, in 16 patients $(13.22 \%)$ by residual choledocholithiasis, in 12 $(9.91 \%)$ by choledocholithiasis with chronic calculous cholecystitis and stenosis papillitis, in 6 (4.95\%) by choledocholithiasis with stenosis of the terminal choledochitis, in $3(2.47 \%)$ fixed concrement of terminal choledochus and chronic calculous cholecystitis, in 2 $(1.65 \%)$ - choledocholithiasis with chronic calculous cholecystitis, complicated by cholecystoduodenal fistula, in 5 patients $(4.13 \%)$ Mirizzi syndrome and in 9 patients $(7.43 \%)$ exacerbation of pancreatitis on the background of choledocholithiasis with chronic calculous cholecystitis.

The duration of EHC with jaundice was determined according to the E. V. Smirnov classification (1974). Acute cholestasis (up to 10 days) was observed in $35.5 \%$ of patients $(n=43)$, prolonged cholestasis (from 10 to 30 days, which after a severe attack took a stable character and lasted up to 4 weeks) was observed in $44.62 \%$ of patients $(n=54)$, and chronic (more than 30 days) - in $19.83 \%$ (in 24 patients).

To solve the tasks, depending on the type of EHC of non-tumoral genesis of patients was divided into 4 groups: EHC type 1 - without jaundice and without damage to hepatocytes $(n=50)$; type 2 EHC - no jaundice with hepatocyte damage $(n=38)$; type $3 \mathrm{EHC}$ - with jaundice without damage to hepatocytes $(n=17)$; type $4 \mathrm{EHC}$ with jaundice and hepatocyte damage $(n=16)$.

The study excluded patients who had concomitant diseases such as viral and autoimmune hepatitis, Carroll's disease, Wilson-Konovalov's disease, Gilbert's syndrome, and oncological genesis of jaundice. The mean age of the examined patients was $58.23 \pm 1.69$ years. The youngest patient was 27 years old, the oldest was 83 . The largest number of patients were patients aged 40 to 69 years, ie most patients were of working age. Most patients were women $(87(71.9 \%))$.

All patients with simultaneous shear-wave elastometry (SWE) on a Soneus P7 apparatus (Kharkiv, UkraineSwitzerland) with a sensor with a frequency of 2-5 $\mathrm{MHz}$ at a depth of not more than $70 \mathrm{~mm}$ from the capsule were performed ultrasound. 7 successful measurements ( $\Sigma$ up 
to $10 \%$, deviation up to 1 ) were evaluated, followed by determination of the median, which characterized the stiffness of the liver tissue in kilopascals $(\mathrm{kPa})$. Stratification of reliable results was performed depending on the ratio of IQR/median - less than $30 \%$.

The concentration of total bilirubin in the serum was determined according to the instructions to the kits of EliTech (France). The activity of alanine-aminotransferase $(A L T)$, aspartate-aminotransferase (AST), alkaline phosphatase (ALP), Y-glutamyltransferase (GGT) serum was determined by ultraviolet kinetics (ALT/GPT, AST - AST/ GOT), recommended by the International Federation of Clinical Chemistry (IFCC) according to the instructions of the EliTech kits (France). The presence of endogenous intoxication (EI) was determined by the content of medium molecular weight peptides (MMP) according to V.V. Nikolaychuk. The MMP fraction consists of aromatic amino acids, which are part of proteins, collagen fibers, aromatic amino acids, among which tyrosine and tryptophan occupy a significant place, and therefore the increase in the content of MMP in serum is a marker of activation of catabolic processes in the body. Fibrosis processes were evaluated by the content of hydroxyproline free (HPf) and glycosaminoglycans (GAG). In serum, the content of GAG was determined according to Rimington, HPf - by Osadchuk, the activation of the inflammatory process in patients was evidenced by a change in the level of alpha-1-acid glycoprotein, the content of which was determined by Weimer [16]. Assessment of biochemical parameters was given according to their content in blood of relatively healthy 20 persons (control group).

In order to optimize the mathematical processing, all the input data was entered into a database built using Microsoft Excel spreadsheets. Statistical processing of the obtained data was performed using SPSS 16.0. For statistical analysis of the data used: $\mathrm{M}$ - mean value, $\mathrm{m}$ error in determining the mean, comparison of mean values of the variables was performed using parametric method (Student's t-test) for the normal distribution of these features, expressed in the interval scale. The correspondence of the type of distribution of signs of the law of normal distribution was checked using the ShapitoWilk method. In other cases, a nonparametric method (the Mana-Whitney $U$ test) was used. The difference in mean values was considered significant at $p<0.05$. To determine the relationship between the data, a correlation analysis was performed with the calculation of the Spearman correlation coefficient $(r)$ [19].

\section{Results}

According to shear wave elastography in patients with $\mathrm{EHC}$ of non-tumoral genesis, the stiffness of the liver varied depending on the increase in the intensity of jaundice and was in patients of group I - 6,021 $\pm 0,223 \mathrm{kPa}$, II - 6,383 $\pm 0,171$ $\mathrm{kPa}$, III - 7,812 $\pm 0,321 \mathrm{kPa}$, in IV $-8,022 \pm 0,364 \mathrm{kPa}(\mathrm{p}<0.001)$, respectively.
It was found that liver stiffness indices for SWE in patients with EHC differed significantly between the study groups and depended on the level of bilirubinemia ( $r=0.84)$ (Fig. 1). The indicators of liver stiffness according to the SWE and the diameter of the choledoch according to the ultrasound are shown in Table 1.

It was found that the liver stiffness indices correlated well with the established choledoch diameter parameters during ultrasound $(r=0.69)$ : I group - $7.582 \pm 0.121 \mathrm{~mm}$; II $8.112 \pm 0.191 \mathrm{~mm}$; III - 9.312 $\pm 0.242 \mathrm{~mm}$; IV - 13.06 $\pm 0.72 \mathrm{~mm}$ (see Table 1 and Figure 2).

Serum bilirubin levels were found to be significantly different in patients with EHC of non-tumorigenic genesis depending on the available jaundice and hepatocyte damage rates, both compared to controls and between the study groups (Fig. 3). Thus, in group II the bilirubin level was 1.5 times higher (34.71 $\pm 3.23 \mu \mathrm{mol} / \mathrm{l})$, in III -6.7 times $(159.0 \pm 12.7$ $\mu \mathrm{mol} / \mathrm{l})$, in IV -13 times $(313.8 \pm 28.1 \mu \mathrm{mol} / \mathrm{l})$. I) relative to patients of group I $(p<0.05)$.

The activity of serum enzymes confirmed cytolytic processes in the liver. Hyperalanine aminotransferasemia and hyperaspartate aminotransferasemia were observed in patients in all groups compared to controls, but changes

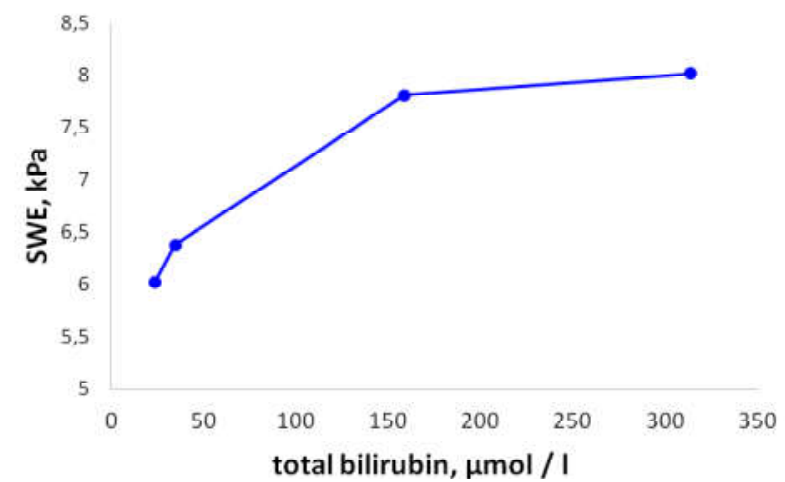

Fig. 1. Dependence of SWE level (kPa) on total serum bilirubin content in patients with non-tumorigenic EHC.

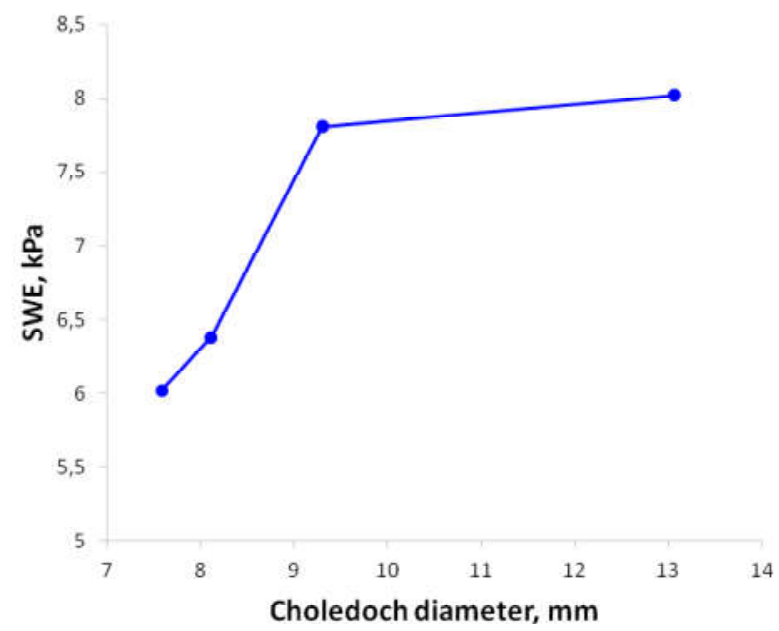

Fig. 2. Dependence of SWE level $(\mathrm{kPa})$ on mean choledoch diameter $(\mathrm{mm})$ in patients with $\mathrm{EHC}$ of non-tumorigenic genesis. 
Table 1. Indicators in patients with different types of extrahepatic cholestasis.

\begin{tabular}{|c|c|c|c|c|}
\hline Indicator & I group $(\mathrm{n}=50)$ & II group $(\mathrm{n}=38)$ & III group $(\mathrm{n}=17)$ & $\mathrm{N}$ group $(\mathrm{n}=16)$ \\
\hline SWE, $\mathrm{kPa}$ & $6.021 \pm 0.223$ & $6.383 \pm 0.171$ & $7.812 \pm 0.321^{* * *} \# \# \#$ & $8.022 \pm 0.364^{* * *} \# \#$ \\
\hline The diameter of the common bile duct, $\mathrm{mm}$ & $7.582 \pm 0.121$ & $8.112 \pm 0.191^{*}$ & $9.312 \pm 0.242^{* * *} \# \# \#$ & $13.06 \pm 0.72^{* * *} \# \# \#^{\circ 00}$ \\
\hline
\end{tabular}

Notes: ${ }^{*}-p<0.01,{ }^{* * *}-p<0.001$ - reliability of differences between indicators of patients of groups II, III, IV and I group; \#\# - $p<0.01$, \#\#\# - $p<0.001$ - reliability of differences between indicators of patients of III and IV groups and II group; ${ }^{\infty}-p<0.001$ - the reliability of the differences between the indicators of patients III and IV group.

in the II and IV groups were more pronounced and probably significant $(p<0.001)$ (Fig. 4).

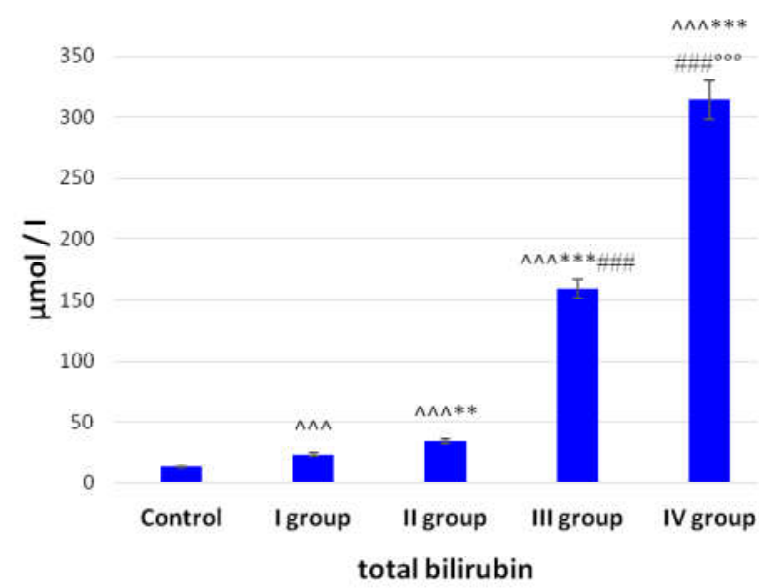

Fig. 3. Total bilirubin level in serum of patients with non-tumor genesis of EHC. ${ }^{\wedge \wedge}$ - $p<0.001$ - significance of the difference between the indicators of patients I, II, III, IV groups and indicators of the control group; ${ }^{* *}-p<0.01,{ }^{* * *}-p<0.001$ - significance of differences between patients of groups II, III, IV and I; \#\# - p<0.001 - significance of difference between indicators of patients of III and IV groups and group II; ${ }^{\circ \circ}$ - $p<0.001$ - significance of the difference between indicators of patients of III and IV groups.

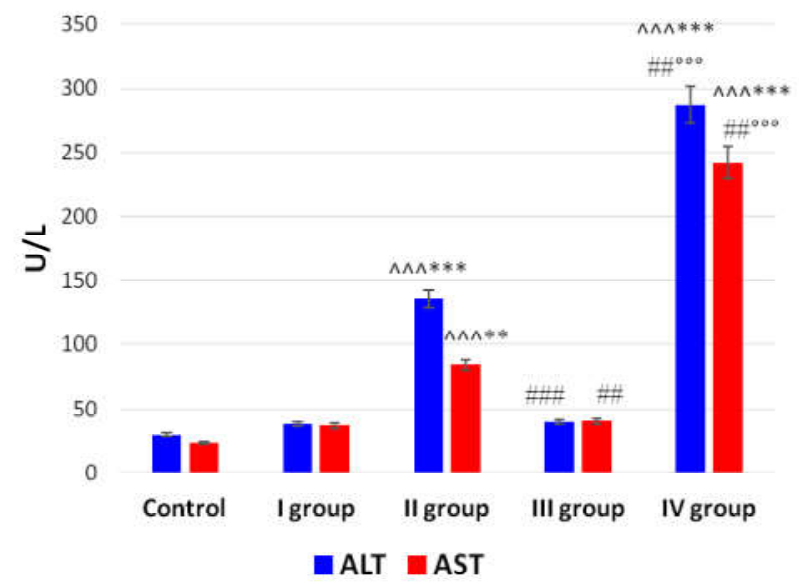

Fig. 4. The activity of liver enzymes in the serum of patients with EHC non-tumoral genesis. ${ }^{\wedge \wedge}$ - $p<0.001$ - significance of the difference between the indicators of patients I, II, III, IV groups and indicators of the control group; ${ }^{* *}-p<0.01,{ }^{* * *}-p<0.001$ significance of the difference between the indicators of patients of II, III, IV groups and group I; - $p<0.01, \quad-p<0.001$ - significance of the difference between indicators of patients of III and IV groups and group II; ${ }^{\circ \circ}$ - $p<0.001$ - significance of difference between indicators of patients of III and IV groups.
The determined values of alanine transaminase in serum by groups: $38.22 \pm 3.45 \mathrm{U} / \mathrm{L}$ in group I; $136.0 \pm 27.8 \mathrm{U} / \mathrm{L}$ in group II; 39.82 \pm 5.11 in group III and $287.0 \pm 44.6 \mathrm{U} / \mathrm{L}$ in group IV $(p<0.001)$. Serum blood alanine transaminase activity was $36.93 \pm 4.14 \mathrm{U} / \mathrm{L}$ in group I; $84.13 \pm 15.50 \mathrm{U} / \mathrm{L}$ in group II; $40.41 \pm 6.80$ in group III, and $242.0 \pm 49.7 \mathrm{U} / \mathrm{L}$ in group IV $(p<0.001)$. Such indicators testify to disturbance of permeability of membranes of hepatocytes and their destruction.

Serum cholestasis markers, in contrast to cytolysis indices, had more pronounced pathological changes in patients with non-tumorigenic EHC, both in comparison with the control group and in patients with group IV: their activity increased - alkaline phosphatase to $284.0 \pm 34.6 \mathrm{U} / \mathrm{L}$ in group I; $262.0 \pm 32.8 \mathrm{U} / \mathrm{L}$ in group II; $310.0 \pm 59.1 \mathrm{U} / \mathrm{L}$ in group III and $630.0 \pm 81.2 \mathrm{U} / \mathrm{L}$ in group IV, respectively, compared with patients in group I $(p<0.001)$ and $Y$ glutamyltransferase up to $247.0 \pm 34.6 \mathrm{U} / \mathrm{L}$ in group I; $345.0 \pm 37.6 \mathrm{U} / \mathrm{L}$ - in group II; $260.0 \pm 41.4 \mathrm{U} / \mathrm{L}$ in group III; to $610.0 \pm 69.9 \mathrm{U} / \mathrm{L}$ in group IV, respectively, compared with patients in group I $(p<0.001)$ (Fig. 5).

Patients with $\mathrm{EHC}$ of non-tumorigenic genesis had activity of inflammatory processes according to the content of alpha-1-acid glycoprotein in blood serum, which was increased 1.9 times to $0.451 \pm 0.041 \mathrm{~g} / \mathrm{l},(p<0.001)$ in patients of group I; 2.6 times to $0.632 \pm 0.053 \mathrm{~g} / \mathrm{l}$ - group II;

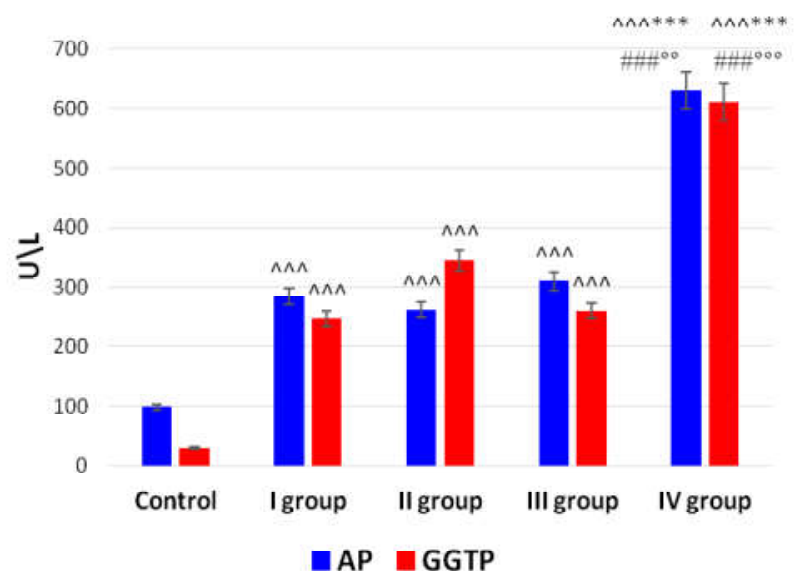

Fig. 5. The activity of liver enzymes in the serum of patients with EHC non-tumoral genesis. ${ }^{\wedge \wedge \wedge}$ - $p<0.001$ - significance of the difference between the indicators of patients I, II, III, IV groups and indicators of the control group; ${ }^{* * *}-p<0.001$ - significance of differences between patients of groups II, III, IV and I; $\quad-p<0.001$ -significance of difference between indicators of patients of III and IV groups and group II; ${ }^{\circ}-p<0.01,{ }^{\circ \circ}$ - $p<0.001$ - significance of the difference between indicators of patients of III and IV groups. 


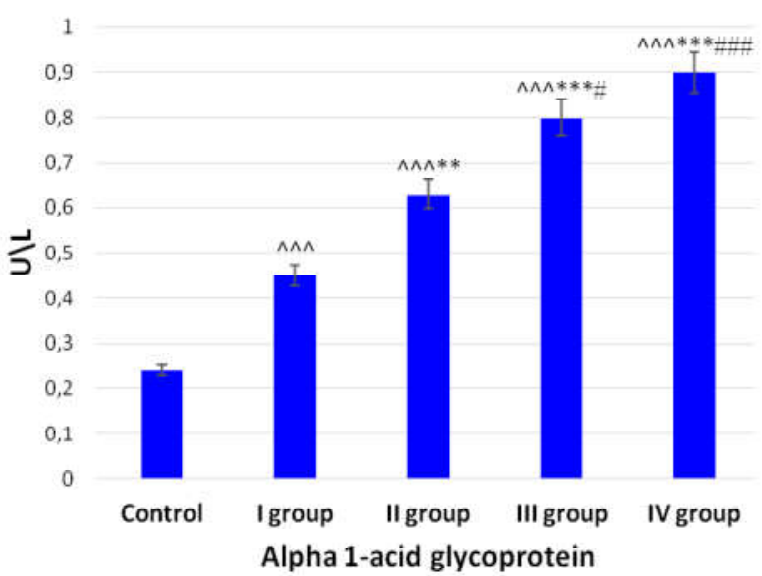

Fig. 6. The content of alpha-1-acid glycoprotein in the serum of patients with $\mathrm{EHC}$ non-tumorigenesis. ${ }^{\wedge \wedge} \mathrm{-} p<0.001$ - significance of the difference between the indicators of patients I, II, III, IV groups and indicators of the control group; ${ }^{* *}-p<0.01,{ }^{* \star *}-p<0.001$ - significance of the difference between the indicators of patients of II, III, IV groups and group I; \#- $p<0.05$, \#\#- $p<0.001$ - significance of the difference between the indicators of patients of III and IV groups and group II.

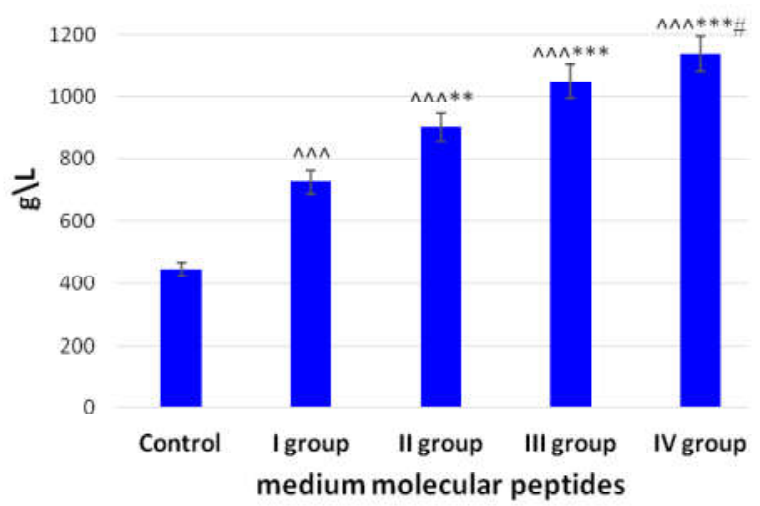

Fig. 7. The level of the average molecular peptides of serum of patients with $\mathrm{EHC}$ of non-tumoral genesis. ${ }^{\wedge \wedge}{ }^{\wedge}-p<0.001$ - significance of the difference between the indicators of patients I, II, III, IV groups and indicators of the control group; ${ }^{* *}-p<0.01,{ }^{* *}-p<0.001-$ significance of the difference between the indicators of patients of II, III, IV groups and group I; \# - p $<0.05$ - significance of difference between indicators of patients of III and IV groups and group II.

3.3 times to $0.801 \pm 0.053 \mathrm{~g} / \mathrm{l}-$ group III; 3.8 times to $0.902 \pm 0.053 \mathrm{~g} / \mathrm{l}$ - group IV $(p<0.001)$, respectively, more pronounced pathological changes were characteristic of patients of III and IV groups compared with patients of group I and control indicators, these changes were accompanied by an increase of ESR in patients of group III to $26.70 \pm 4.80$ $\mathrm{mm} / \mathrm{g}$ and group IV up to $31.20 \pm 3.60 \mathrm{~mm} / \mathrm{g}(\mathrm{p}<0.05)$, as well as an increase in leukocyte levels, which reflected the general inflammatory response of the body (Fig. 6).

The analysis of the data obtained showed a gradual increase in the content of medium-molecular peptides in the serum of patients, depending on the intensity of EHC. The presence of endotoxemia was present in patients of all groups: significant changes were observed in patients of group II, which showed an increase in the concentration of medium-molecular peptides in the serum in 1.3 times to $902.0 \pm 56.4 \mathrm{~g} / \mathrm{l}(\mathrm{p}<0.01)$ relative to patients of group I (Fig. 7).

It should be emphasized that in patients of group I, in which the patency disorders were associated with longterm phenomena of $\mathrm{EHC}$ without jaundice and lesions of hepatocytes - endogenous intoxication syndrome was formed already at the initial stage of EHC development, and with the increase in bilirubinemia, the content of medium molecular peptides, accordingly, in groups III and IV almost: 1.5 to $1050 \pm 76 \mathrm{~g} / \mathrm{l}(\mathrm{p}<0.001)$ and 1.7 times to $1139 \pm 78 \mathrm{~g} / \mathrm{l}(\mathrm{p}<0.01)$, respectively, relative to patients of group I; 2.4 and 2.6 times relative to the control group $(p<0.001)$ (see Fig. 7).

There was a gradual decrease in the serum hydroxyproline free content of patients in all groups compared to the control group (Fig. 8). It is impossible to exclude the fact that with the progression of non-neoplastic $\mathrm{EHC}$, there is an imbalance between the synthesis and disintegration of collagen in these patients, which indicates a decrease in the process of collagen degradation, which was more pronounced in patients of group IV, where its content decreased in 2-times to $5,232 \pm 0,631 \mu \mathrm{mol} / \mathrm{l}$ $(p<0.01)$ relative to group I $(10.72 \pm 1.90 \mu \mathrm{mol} / \mathrm{I})$ and in 1.8 times relative to group II $(9.633 \pm 1.201 \mu \mathrm{mol} / \mathrm{l}, \mathrm{p}<0.01)$ (see Fig. 8).

Increase in GAG concentration in serum was observed in patients of all groups. In group II, this indicator increased 1.4 times to $6.430 \pm 0.671 \mathrm{mmol} / \mathrm{I}(p<0.05)$; in group III -1.6 times to $7.133 \pm 0.711 \mathrm{mmol} / \mathrm{l}(p<0.05)$; in group IV -1.8 times to $8.140 \pm 0.482 \mathrm{mmol} / \mathrm{l}(p<0.001)$, respectively, in comparison with patients of group I, indicating the increased breakdown of carbohydrate-protein components of connective tissue, increasing their content in the serum

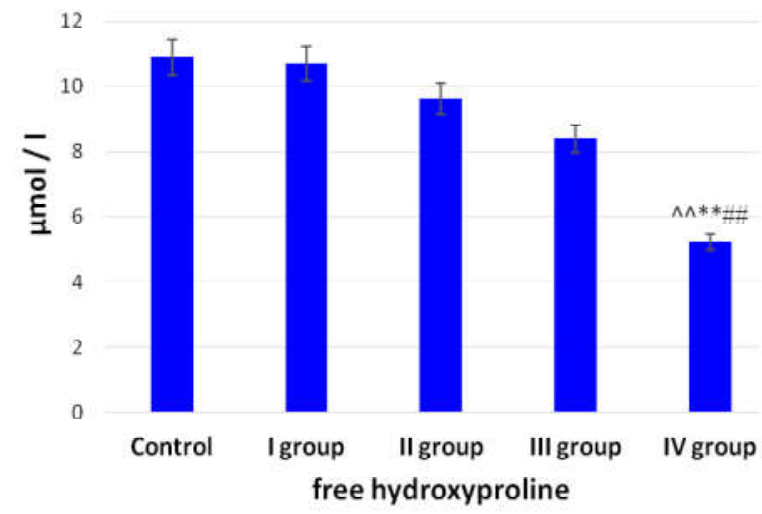

Fig. 8. Level of hydroxyproline free in serum of patients with EHC of non-tumoral genesis. ${ }^{\wedge}$ - $p<0.01$ - significance of the difference between the indicators of patients I, II, III, IV groups and indicators of the control group; ${ }^{* *}-p<0.01$ - significance of the difference between the indicators of patients of II, III, IV groups and group I; \#\# - p<0.01 - significance of difference between indicators of patients of III and IV groups and group II. 
indicates the activity of the inflammatory process, the duration of which leads to the destruction of liver tissues.

\section{Discussion}

The results of the study indicate that in patients with EHC significantly disrupt the biochemical composition of blood serum, which is determined before all types of EHC, which are significantly different in terms of choledochal diameter, liver stiffness, severity of hepatic and cellular insufficiency, El markers and nonspecific fibrosis markers.

According to SWE, EHC, depending on the available jaundice and hepatocyte damage, definitely affects the elasticity of the liver, regardless of the presence of liver fibrosis/cirrhosis, with an increase in choledoch diameter, liver stiffness and their ratio $(r=0.69)$ in the case of existing $\mathrm{EHC}$ processes are associated with worsening of bile flow, inflammatory phenomena in the ductal system and, as a consequence, increased hydrostatic pressure in the ducts and edema of the liver parenchyma, which is confirmed by other studies [11-13, 20-22, 24-27].

The liver is one of the first organs whose functions are altered as a result of impaired bile flow in EHC of nontumorigenesis. The presence of signs of cholestasis was associated with more significant changes in the activity of serum enzymes of serum, with a more pronounced cytolytic and cholestatic syndrome with increasing intensity of cholestasis. A similar pattern was observed with regard to the content of $\alpha 1$-acid glycopeptide in blood serum, the value of which was highest in patients of group IV with nonneoplastic EHC and showed activation of inflammatory processes in the body, revealed changes were accompanied by an increase in leukocyte and ESR levels inflammatory response of the body.

An important pathogenetic syndrome of homeostasis disorders in virtually all diseases is endogenous intoxication - an integral concept that includes a number of components: the accumulation of intermediates of impaired metabolism and metabolites, endogenous and bacterial toxins, aggressive biologically active substances, inflammatory factors in combination with hypoxia and

\section{References}

[1] Banerzhi, A., \& Parasich, I. V. (2014). Medical Statistics Clear Language. Moscow: Practice medicine. ISBN: 978-5-98811087-3.

[2] Bergman, S., Al-Bader. M., Sourial, N., Vedel, I., Hanna, W. C., Bilek, A. J. ... Fraser, S. A. (2015). Recurrence of biliary disease following non-operative management in elderly patients. Surgical Endoscopy, 29(12), 3485-3490. doi: 10.1007/s00464015-4098-9.

[3] Endoscopic management of common bile duct stones: European Society of Gastrointestinal Endoscopy (ESGE) guideline. Endoscopy. (2019). Available from: https:// www.ncbi.nlm.nih.gov/pubmed/30943551. Accessed: 2019 May 51(5), 472-491. doi: 10.1055/a-0862-0346.

[4] Gaidar, lu. A., Ostrovs'kii, O. S., Ratchik, V. M., \& Kononov, I. M. (2007). Features of morphological liver damage in the dynamics of obstructive cholestasis in the clinic and disorders of microcirculation [14, 15, 23]

Occurrence in the blood of non-oxidized products of lipid metabolism (acetone, acetoacetic and $\beta$ Hydroxybutyric acid), increase in the level of ketones, medium-molecular peptides cause the development of the clinical picture of endogenous intoxication syndrome. The obvious important role of the liver, as a body of metabolic detoxification, in the process of formation of $\mathrm{El}$ in the body, as well as the processes of cytolysis and cholestasis.

Therefore, extrahepatic cholestasis of non-tumoral genesis is accompanied by certain metabolic disorders and ultrastructural changes that lead to impaired cell-tissue metabolism, the appearance of a large number of aggressive active substances, the reduction of the inactivation and elimination of toxins, that accumulate in the patient and leads to the development of general endotoxemia.

Given the data obtained, it is promising to further study liver stiffness under conditions of surgical correction as a non-invasive way of monitoring the syndrome of "rapid discharge" of bile in patients with non-hepatic cholestasis of non-tumoral genesis.

\section{Conclusions}

1. Indicators of liver stiffness according to SWE data in patients of all groups with extrahepatic cholestasis of nontumoral genesis depend on the level of bilirubinemia $(r=$ 0.84 ), and in patients with hepatocyte damage (II and IV group) also on the duration of cholestasis $(r=0.69)$ but cannot serve as an objective indicator of liver functional status.

2. Patients with extracorporeal cholestasis of nontumoral genesis without the appearance of jaundice and hepatocyte damage revealed an increase in endotoxemia indicators $(p<0.001)$, which indicates developing of EHC.

3. Extrahepatic cholestasis of non-tumorigenesis is accompanied by a gradual increase in alkaline phosphatase and y-glutamyltransferase activity, while bilirubin levels cannot serve as an indicator of long-term EHC.

experiment. Morphology, 1(2), 41-46. doi: 10.26641/19979665.2007.

[5] Kamyshnikov, V. S. (2002). Reference Book of Clinical and Biochemical Laboratory Diagnostics. Minsk: Belarus. ISBN: 985-01-0444-9.

[6] Kanikovs'kij, O. E., Bondarchuk, O. I., Karij, Ja. V., \& Babijchuk, Ju. V. (2015). Surgical tactics of treatment complicated forms of gallstone disease in elderly and senile patients. Ukrainian Journal of Surgery, 3-4(26-27), 109-113.

[7] Kashaeva, M. D., Proshin, A. V., Afanas'ev, A. N., Gavrilova, K. V., \& Golushko, A. V. (2018). Liver morphology in mechanical jaundice. Bulletin of Novgorod State University, 6(112), 8-11.

[8] Kim, D. K., Choi, J. Y., Park, M. S., Kim, M. J., \& Chung, Y. E. (2018). Clinical feasibility of MRE lastography in patients with biliary obstruction. $A J R, 210(6), 1273-1278$. doi.org/10.2214/ AJR.17.19085. 
[9] Kliaritskaia, I. L., Shelikhova, E. O., Moshko, lu. A., Semenikhina, E. V., Krivoi, V. V., \& Tsapiak, T. A. (2017). Elastometry in the diagnosis of liver diseases. Crimean Therapeutic J., 2, 2835.

[10] Kubo, K., Kawakami, H., Kuwatani, M., Nishida, M., Kawakubo, K., Kawahata, S. ... Sakamoto, N. (2016). Liver elasticity measurement before and after biliary drainage in patients with obstructive jaundice: a prospective cohort study: a prospective cohort study. BMC Gastroenterol., 6(1), 65. doi: 10.1186/s12876-016-0479-3.

[11] Kushaeva, M. D., Proshin, A. V., Afanas'ev, A. N., Gavrilova, K. V., \& Golushko, A. V. (2018). Liver morphology in mechanical jaundice. Bulletin of Novgorod State University, 112(6), 8-11.

[12] Millonig, G., Reimann, F. M., Friedrich, S., Fonouni, H., Mehrabi, A., Büchler M. W. ... Mueller S. (2008). Extrahepatic Cholestasis Increases Liver Stiffness (FibroScan). Irrespective of Fibrosis Hepatology, 48(5), 1718-1723. doi: 10.1002/hep.22577.

[13] Natal'skij, A. A., Tarasenko, S. V., Zajcev, O. V., \& Peskov, O. D. (2014). Current ideas about liver failure in surgery. Russian Medical and Biological Bulletin named acad. I.P. Pavlova, 4, 42-49.

[14] Nikolaichuk, V. V., Moin, V. M., \& Kirkovskii, V. V. (1991). The method of determining "medium molecular peptides". Laboratory science, 10, 13-16.

[15] Nikol'skaia, V. A., Danil'chenko, lu. D., \& Memetova, Z. N. (2013). Biochemical aspect of the consideration of the role of mediummass molecules in the body. Scientific Notes of Taurida National University named V.I. Vernadsky, series "Biology, Chemistry", 65(56), 1, 139-145.

[16] Osadchuk, M. A., \& Kapustin, V. M. (1987). Protein-bound plasma oxyproline in acute viral hepatitis. Laboratory Science, 7, 16-18.

[17] Sadiku, E., Taci, S., Dibra, A., Nela, E., \& Babameto, A. (2019). The differential diagnosis of intra and extra-hepatic cholestasis: Causes and diagnosis of intrahepatic cholestatic disorders. Hepatology. Retrieved from: http://www.ishp.gov.al/ the-differential-diagnosis-of-intra-and-extra-hepaticcholestasis-causes-and-diagnosis-of-intrahepaticcholestatic-disorders/

[18] Sergeeva, E. A., Burdina, E. G., \& Minushkin, O. N. (2014).
Cholestasis syndrome. Kremlin Medicine. Clinical Herald, 3 , 84-90.

[19] Shen, Q. L., Chen, Y. J., Wang, Z. M., Zhang, T. C., Pang, W. B., Shu, J., \& Peng, C. H. (2015). Assessment of liver fibrosis by Fibroscan as compared to liver biopsy in biliary atresia. World J. Gastroenterol., 21(22), 6931-6936. doi: 10.3748/ wjg.v21.i22.6931.

[20] Siplivyi, V. A., Evtushenko, D. V., Naumova, O. V., Andreeshchev, S. A., \& Evtushenko, A. V. (2016). Morphological changes of the liver in obturation jaundice, caused by choledocholithiasis, depending on its duration. Clinical Surgery, 2, 20-23.

[21] Smith, I., Monkemuller, K., \& Wilcox, C. M. (2015). Incidentally identified common bile duct dilatation: a systematic review of evaluation, causes, and outcome. J. Clin. Gastroenterol, 49(10), 810-815. doi: 10.1097/MCG.0000000000000394.

[22] Soumitra R., Eachempati S., \& Reed R. (2015). Acute Cholecystitis. Springer International Publishing, 225. doi: 10.1007/978-3-319-14824-3_1.

[23] Tereshchenko, O. A., Botashev, A. A., Pomeshchik, lu. V., Petrosian, E. A., \& Sergienko, V. I. (2012). Syndrome of endogenous intoxication and systemic inflammatory reaction in biliary peritonitis complicated by abdominal sepsis. Bulletin of Experimental and Clinical Surgery, 5(4), 722-726.

[24] Tonozuka, R., Itoi, T., Sofuni, A., Itokawa, F., Kurihara, T., Tsuchiya, T. ... Moriyasu, F. (2014). Efficacy and safety of endoscopic papillary large balloon dilation for large bile duct stones in elderly. Itokawa Digestive Diseases and Sciences, 59(9), 2299-2307. doi: 10.1007/s10620-014-3156-9.

[25] Trifan, A., Sfarti, C., Cojocariu, C., Dimache, M., Cretu, M., Hutanasu, C., \& Stanciuet C. (2011). Increased liver stiffness in extrahepatic cholestasis caused by choledocholithiasis. Hepat. Mon., 11(5), 372-375. PMC3212780.

[26] Tsyrkunov, V. M., Prokopchik, N. I., Andreev, V. P., \& Kravchuk, R. I. (2018). Clinical Morphology of liver: Cholestases. Journal of the Grodno State Medical University, 16(4), 468-480. doi: 10.25298/2221-8785-2018-16-4-468-480.

[27] Zaharova, A. V. (2017). Perfection of diagnostic and surgical tactics in patients with obstructive jaundice. Practice Medicine, 67(2), 56-63.

\section{СТРУКТУРНО-ФУНКЦІОНАЛЬНИЙ СТАН ПЕЧІНКИ У ХВОРИХ З ПОЗАПЕЧІНКОВИМ ХОЛЕСТАЗОМ НЕПУХЛИННОГО ГЕНЕЗУ} Шевченко Б.Ф., Зеленюк О.В., Кленіна І.А., Бабій О.М.

На сьогоднішній день діагностика та лікування позапечінкового холестазу (ПХС) на різних етапах розвитку залишається однією з найактуальніших проблем сучасної біліарної хірургії. Мета дослідження - визначити структурні зміни печінки у пацієнтів з позапечінковим холестазом непухлинного генезу за даними зсувнохвильової еластометрії та ультразвукового дослідження у співставленні з біохімічними показниками ендотоксемії, запалення та маркерами фріброзу. Передопераційно обстежили 121 хворого з ПХС непухлинного генезу: провели стандартні загальноклінічні дослідження, ультразвукове дослідження печінки та їі зсувнохвильову еластометрію. В залежності від наявності жовтяниці та симптомів пошкодження гепатоцитів усіх досліджених розподілили на 4 групи. Визначали вміст у сироватиі крові середньомолекулярних пептидів, вільного гідроксипроліну та глікозоаміногліканів. Статистичну обробку отриманих даних проводили з використанням програми SPSS 16.0. У пацієнтів з ПХС непухлинного генезу за даними зсувнохвильової еластографії жорсткість печінки змінювалася в залежності від збільшення інтенсивності жовтяниці. Встановлено, що рівень білірубіну у сироватці крові у таких пацієнтів достовірно відрізнявся в залежності від наявної жовтяниці та симптомів пошкодження гепатоцитів як порівняно з даними контрольної групи, так і між дослідженими групами. При ПХС структурні зміни печінки залежать від порушень біохімічного складу сироватки крові, які суттєво змінюються при тривалому позапечінковому холестазі та проявляються вираженою печінковою недостатністю. Таким чином, у пацієнтів з наявним позапечінковим холестазом непухлинного генезу без жовтяниці та пошкодження гепатоцитів виявлено збільшення показників ендотоксемії ( $р<0,001)$, що свідчить про розвиток холестазу; показники жорсткості печінки залежать від рівня білірубінемії (r = 0,84), а у пацієнтів з пошкодженням гепатоцитів ще і від тривалості холестазу $(r=0,68)$. Рівень білірубіну не може бути індикатором тривалості позапечінкового холестазу.

Ключові слова: позапечінковий холестаз непухлинного генезу, еластометрія, маркери ендогенної інтоксикації, пошкодження гепатоцитів. 


\section{СТРУКТУРНО-ФУНКЦИОНАЛЬНОЕ СОСТОЯНИЕ ПЕЧЕНИ У БОЛЬНЫХ С ВНЕПЕЧЕНОЧНЫМ ХОЛЕСТАЗОМ НЕОПУХОЛЕВОГО ГЕНЕЗА \\ Шевченко Б.Ф., Зеленюк А.В., Кленина И.А., Бабий А.М.}

На сегодняшний день диагностика и лечение внепеченочного холестаза (ВПХ) на разных этапах развития остается одной из самых актуальных проблем современной билиарной хирургии. Цель исследования - установить структурные изменения печени у пациентов с внепеченочными холестазом неопухолевого генеза по данным сдвиговолновой эластометрии и ультразвукового исследования в сопоставлении с биохимическими показателями эндотоксемии, воспаления и маркерами фриброза. Предоперационно обследовали 121 больного с ВПХ неопухолевого генеза провели стандартные общеклинические исследования, ультразвуковое исследование печени и ее сдвиговолновую эластометрию. В зависимости от наличия желтухи и симптомов повреждения гепатоцитов всех исследованных разделили на 4 группы. Определяли содержание в сыворотке крови среднемолекулярных пептидов, свободного гидроксипролина и гликозаминогликанов. Статистическую обработку полученных данных проводили с использованием программы SPSS 16.0. У пациентов с ВПХ неопухолевого генеза по данным сдвиговолновой эластографии жесткость печени менялась в зависимости от увеличения интенсивности желтухи. Установлено, что уровень билирубина в сыворотке крови у таких пациентов достоверно отличался в зависимости от имеющейся желтухи и симптомов повреждения гепатоцитов как по сравнению с данными контрольной группы, так и между исследованными группами. При ВПХ структурные изменения печени зависят от нарушений биохимического состава сыворотки крови, которые существенно изменяются при длительном внепеченочном холестазе и проявляются выраженной печеночной недостаточностью. Таким образом, у пациентов с имеющимся ВПХ неопухолевого генеза без желтухи и повреждения гепатоцитов выявлено увеличение показателей эндотоксемии ( $p<0,001)$, что свидетельствует о развитии холестаза; показатели жесткости печени зависят от уровня билирубинемии ( $r=0,84)$, а у пациентов $c$ повреждением гепатоцитов еще и от длительности холестаза $(r=0,68)$. Уровень билирубина не может быть индикатором длительности внепеченочного холестаза.

Ключевые слова: внепеченочный холестаз неопухолевого генеза, эластометрия, маркеры эндогенной интоксикации, повреждение гепатоцитов. 